\title{
Nanomole per Kilogram
}

National Cancer Institute

\section{Source}

National Cancer Institute. Nanomole per Kilogram. NCI Thesaurus. Code C85754.

Nanomoles per kilogram. 